\title{
Agroforestry and Management of Trees in Bunya County, Mayuge District, Uganda
}

\author{
Monica Kyarikunda, ${ }^{1}$ Antonia Nyamukuru, ${ }^{2}$ Daniel Mulindwa, ${ }^{3}$ and John R. S. Tabuti ${ }^{2,4}$ \\ ${ }^{1}$ Bishop Stuart University, P.O. Box 09, Mbarara, Uganda \\ ${ }^{2}$ Sustainable Use of Plant Diversity (SUPD), P.O. Box 16794, Wandegeya, Uganda \\ ${ }^{3}$ Department of Environmental Management, College of Agriculture and Environmental Sciences, Makerere University, \\ P.O. Box 7062, Kampala, Uganda \\ ${ }^{4}$ College of Agricultural and Environmental Sciences (CAES), Makerere University, P.O. Box 7062, Kampala, Uganda
}

Correspondence should be addressed to Monica Kyarikunda; kmonicam@yahoo.com

Received 17 February 2017; Accepted 30 April 2017; Published 31 May 2017

Academic Editor: Piermaria Corona

Copyright (C) 2017 Monica Kyarikunda et al. This is an open access article distributed under the Creative Commons Attribution License, which permits unrestricted use, distribution, and reproduction in any medium, provided the original work is properly cited.

\begin{abstract}
Woody plant resources continue to disappear in anthropogenic landscapes in Uganda. To slow down further loss of these resources requires the collaboration of farmers in tree planting in agroforestry systems. Tree planting interventions with the collaboration of farmers require a good understanding of tree management practices as well as trees that best satisfy farmers' needs. We carried out this research to determine (1) the most preferred tree species and reasons why they are preferred, (2) the species conservation statuses, and (3) existing tree management practices and challenges to tree planting. Fourteen priority species valued because they yield edible fruits and timber have been prioritised in this study. Farmers are interested in managing trees but are constrained by many factors, key among which is scarcity of land and financial capital to manage tree planting. Trees are managed in crop fields and around the homestead. From farmers' reports, the highly valued species are increasing in the landscape. In conclusion, the potential to manage trees in agroforestry systems exists but is hampered by many challenges. Secondly, the liking of trees that supply edible fruits seems to support the welfare maximisation theory which ideally states that rural people manage trees with the aim of having regular access to products that satisfy their household needs and not for income generation.
\end{abstract}

\section{Introduction}

Woody species (i.e., tree and shrubs) are threatened with local extinction and are disappearing fast, most especially in tropical Africa [1, 2]. In Uganda tree loss is rapidly growing and is estimated at $1.8 \%$ per year [3]. This rate of tree loss is fastest in anthropogenic landscapes outside protected areas where it is estimated to occur at a rate of $2.27 \%$ per annum. For this reason the forest estate outside protected areas reduced from 3.46 million to 2.3 million ha between 1990 and 2005, a difference of about 1.16 million ha. Mayuge District, where this study was conducted, is one of the districts that has had the greatest loss of woody species and has lost almost all its forest cover [3].

The reasons that lead to loss of trees are chiefly land use change. In most parts of the world including Uganda land cover has been converted from woodlands or forests to create land for crop and livestock agriculture. The underlying cause for most of the land use change and consequently woody cover loss, in Uganda, is human population growth. The rapid human population growth estimated at more than $3 \%$ per annum has increased demand for land for cultivation and settlement, as well as woody products. In Uganda people exploit woody resources as fire wood, for timber and poles for construction purposes [4]. As an example of the level of woody species demand, over $95 \%$ of Uganda's households depend on firewood and charcoal for their energy needs and $91 \%$ of all roundwood consumed is consumed as fuelwood [5]. It is this extensive consumption of tree products that leads to overexploitation and land cover change.

The rapid loss of trees and shrubs threatens livelihoods that are dependent on those resources. Human populations, 
globally, depend very much on plant resources for their sustenance and economy [1], for example, the use of fuelwood for cooking. In addition plants (woody or otherwise) also generate ecosystem services that are invaluable to humans in ways such as rainfall generation or provision of nectar for pollinators. Because of these reasons, the rate of woody species loss must be slowed in Uganda.

To address the challenge of fast tree cover loss in Uganda will require increases in rates of tree planting. At present Uganda has made important strides in tree planting on lands outside protected areas through interventions for establishment of tree plantations. However, most of these interventions such as the Sawlog Production Growers Scheme (SPGS) have targeted large plantation farmers and have ignored small holder farmers. Successful increase in tree/shrub cover requires the participation of small holder farmers because they own most of the land in Uganda: approximately $70 \%$ of all land in Uganda is privately owned by small holder farmers [6]. This means therefore that small holder farmers are invaluable stakeholders in interventions for increasing tree/shrub cover in Uganda.

To involve farmers, we need to understand their attitudes and perceptions concerning tree management, how they currently manage species, and what challenges hinder tree growing or which opportunities exist for growing trees. Farmers make decisions whether to participate or not in interventions such as tree growing based on considerations of how such interventions maximise their welfare and also fit into their livelihood strategy and available resources [79]. Overall these decisions are also influenced by historical events such as circumstances that have directed resource availability. According to Miller et al., [8], analysing people's decisions can reveal key variables that affect their behaviours and which can therefore be used to design successful and sustainable interventions.

Additionally, farming systems include a wide variety of agroforestry practices. These tend to vary from place to place in both extent and intensity of management [10] in line with the varying agroecological and socioeconomic factors prevailing in those areas. This validates the need to make agroforestry studies location-specific and avoid too much generalization especially by development organizations [11]. This study was undertaken in Mayuge District to address an otherwise ignored topic and to increase understanding about the perception and behaviour of farmers towards the potential of adoption of agroforestry systems to ameliorate the environmental challenges of Uganda. We specifically determined (1) the most preferred tree species and reasons why they are preferred, (2) the species conservation statuses, and (3) existing tree management practices and challenges to tree planting.

\section{Study Area and Methods}

Bunya County is found in Mayuge District, Eastern Uganda, at $00^{\circ} 12^{\prime} \mathrm{N}, 33^{\circ} 32^{\prime} \mathrm{E}$, and approximately $120 \mathrm{~km}$ from Kampala the Capital City of Uganda. The district neighbours other major towns, namely, Iganga and Jinja. This means that there is high demand for tree products.

The district has a tropical climate with a bimodal rainfall pattern with peaks in March-May and October-November; the rainfall ranges between 900 and $1200 \mathrm{~mm}$ per annum. The district is endowed with fertile soils and hence has high potential for agriculture. The topography is relatively flat with high ridges and isolated hills, wavy low lands, and open water reserves [12]. The soils are skeletal, shallow, or poorly drained and are characterized mostly as Nitisols and Luvisols.

The vegetation of Mayuge has adversely been affected by rapid population growth with its attendant problems of deforestation, environmental degradation, and pollution [12]. Between 1990 and 2005, the district lost $97 \%$ of its forest cover, starting with 15,000 ha in 1990; only 450 ha were remaining by 2005 . In the same period agriculture increased by more than $200 \%$ from 660 ha in 1990 to 2006 ha in 2005 [3].

The population of the district is estimated at approximately 473,000 people and the population density at 440 people $/ \mathrm{km}^{2}$ [13]. The main source of livelihood is subsistence farming. Sixty-two percent of the population is 19 years of age or less. Most of the agriculture in the district is on the subsistence level. However, there is commercial sugar cane growing that is increasing and many residents are cutting down trees to establish sugar cane plantations (Makerere takes climate change project to Mayuge to encourage farmers to plant trees (http://caes.mak.ac.ug/news/news-archieve/ 1235-makerere-takes-climate-change-project-to-mayuge-toencourage-farmers-to-plant-trees.html)). The economic activities include crop cultivation (e.g., maize, cassava, groundnuts, cocoa, cotton, coffee, beans, sweet potatoes, and millet) and fishing. All these demographic and socioeconomic characteristics point to a high potential to overexploit tree resources and to convert land cover to agriculture.

2.1. Methods. Field work for this study was carried out between July and September 2012. The study adopted an ethnobotanical approach. We conducted interviews using structured open and close ended questionnaire in face to face interviews with household heads.

Respondents were selected using multistage sampling procedure based on administrative units. In Uganda 5 or 6 villages make a parish, a similar number of parishes make a subcounty, and a similar number of subcounties are collected to make a county. Using random sampling procedure, three subcounties were selected from each county and, from each of these, one parish was randomly selected. Lastly, from each selected parish one village was selected. Thirty households were then selected from each of the three villages to make a total of 90 respondents ( 44 of these were female).

The interviews were designed to collect information on the most preferred species. Free listing techniques were used, where informants were requested to list ten species that came first to mind. This technique was important because the aim was to focus on the most important species and people tend to mention important species first [14]. Interviews also investigated respondent perceptions of trees conservation status; tree management practices, ownership of tree resources (tree 
tenure systems), tree products marketing, and threats and constraints to the management of woody plant species; and also the personal profiles of the respondents. Respondents were asked to give the current state of woody tree species by listing down species that are locally increasing or reducing and factors contributing to these changes. Every interview lasted about 30 minutes. At the end of the interview every household was given a token of appreciation to compensate for time spent in interviews. Although rewarding respondents is a controversial issue among researchers, some have recommended it on grounds of ethics and efficiency [15], and we share a similar opinion.

Voucher specimens were collected and taken to Makerere University Herbarium (MHU) where identification and archiving were done. The survey data was summarised into frequencies/percentages using Microsoft Excel 2007. To test for relationships within the data set, frequencies were computed and chi-square tests were carried out on cross tabulations. Preferences were ranked based on frequencies considering the species with higher frequencies to be the most preferred.

A use value was computed for each species using the expression below:

$$
V_{s}=\sum \frac{f_{i}}{n}
$$

where $V_{s}$ is the use value for a species $s, f_{i}$ is the frequency of mentioning a given use of species $s$ by respondents, and $n$ is the total number of respondents in the study (see Nyamukuru et al. [16] for a description).

\section{Results}

3.1. Respondents' Socioeconomic Characteristics. The respondents interviewed in this study were mostly peasant farmers (82\%) who earn their livelihood through subsistence farming of food crops that include maize, cassava, sorghum, and sweet potatoes and also cash crops like sugar cane. The respondents are mostly Christians of mixed denominations: Protestants, Catholics, and Pentecostals (Table 1). They are affiliated to 13 tribes, dominated by the Basoga (59\%) and the Japadholas (14\%). Other tribes included Bagisu, Banyole, Atesots, Badama, Baluya, Bakedi, and Bagwere. They have little or no formal education, not exceeding secondary level or 13 years of education.

\subsection{Preferred Woody Species and Their Values. Fourteen tree} species are valued by the people of Bunya County. The species have been prioritised based on computed use values and reports by respondents that they are grown by the people of Bunya and that they will continue to grow them in the future and also because the species were mentioned by $30 \%$ or more of the respondents (Table 2). An additional three species Eucalyptus spp., Senna siamea, and Senna spectabilis, though not shown in Table 2, because they had very low total use values $(=0.20)$, are considered: Eucalyptus was liked by farmers and $15 \%$ had plans to plant it, while the Senna species were being planted by $24 \%$ of the farmers.
TABLE 1: Respondents' sociodemographic details $(n=90)$.

\begin{tabular}{lc}
\hline Attribute & Percentage \\
\hline Age & \\
$<30$ & 26 \\
$30-49$ & 40 \\
$50-69$ & 30 \\
$>70$ & 4 \\
Education & \\
None & 31 \\
Primary & 42 \\
Secondary & 23 \\
Tertiary & 3 \\
Sex of household head & \\
Female headed & 23 \\
Male headed & 77 \\
Tribe & \\
Musoga & 59 \\
Japadhola & 14 \\
Muganda & 6 \\
Other tribes & 21 \\
Religion & \\
Moslem & 43 \\
Protestant & 32 \\
Catholic & 20 \\
Pentecostal & 4 \\
\hline
\end{tabular}

These priority species are multipurpose that yield products that include edible fruits, timber, construction, and firewood. The most frequently mentioned species were Mangifera indica L. (93\%), Artocarpus heterophyllus Lam. (99\%), and Persea Americana Mill. (86\%), and these were mostly valued for their edible fruits (see Table 2). Milicia excelsa (Welw.) C. Berg and Pinus spp. were preferred for their timber. Some of these especially Coffea canephora Froehner are sold to earn incomes. For example, all species except Carica papaya L. can be used as firewood, but the topmost three for firewood are Maesopsis eminii Engl., Senna spp., and Eucalyptus spp.

Some species are known to deliver the following ecosystem services: providing shade for crops (e.g., Ficus sycomorus L.); creating wind breaks; contributing to rain fall formation; enriching soils (fixing nitrogen in the soil), keeping soils moist, and controlling soil erosion; and adding scenic beauty. These values were mentioned by few respondents leading to low computed use values. For this reason, these environmental services as well as the species known to provide them are not included in Table 2 . All the priority species are introduced and naturalised apart from M. excelsa, M. eminii, and Canarium schweinfurthii Engl. that are indigenous and Pinus spp. that are exotic.

Some tree products are sold to earn incomes; however, only $7 \%$ of the respondents sell tree products to get income, and they sell mostly edible fruits. Other products commonly sold and the species that they are gathered from are shown in Table 3 . The products are sold at farmers homes (87\%), but, 


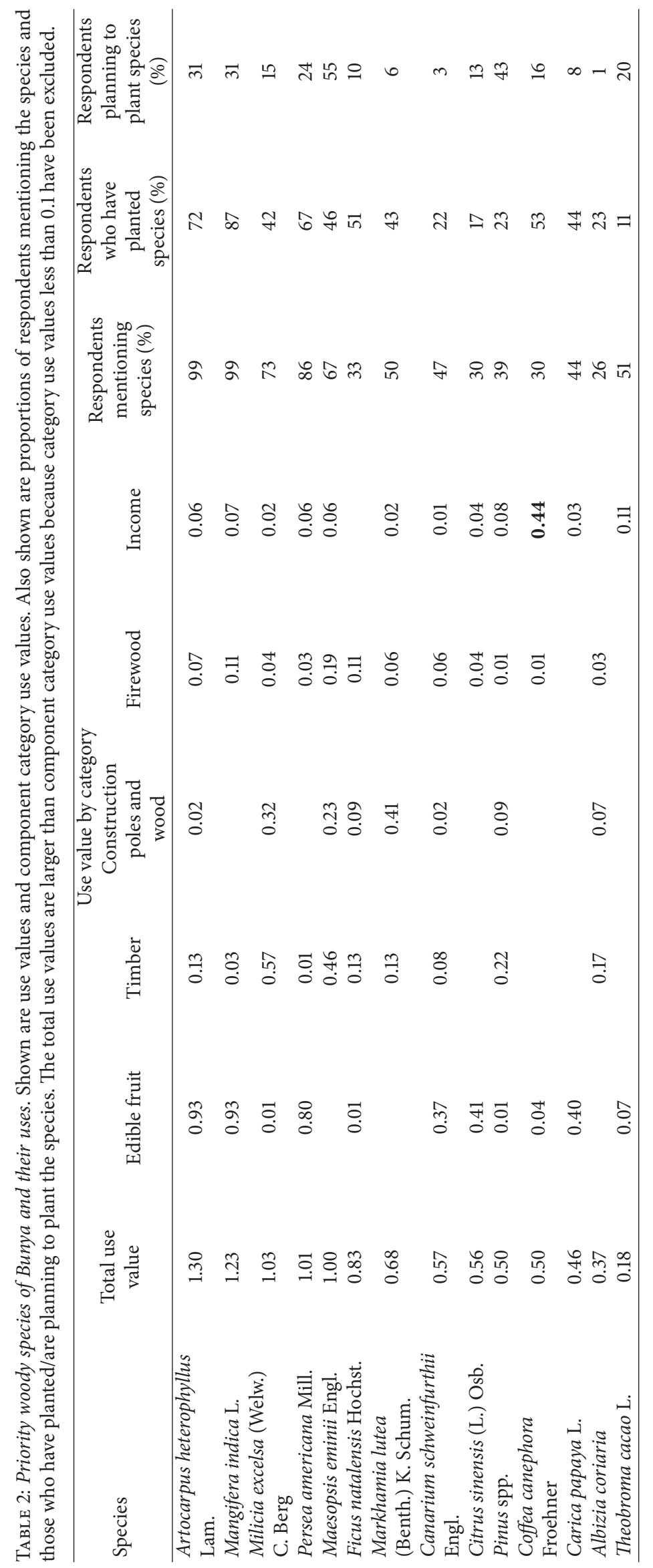


TABLE 3: Species and products sold in the study area. The numbers are frequencies of respondents who say that products from species are sold for money.

\begin{tabular}{|c|c|c|c|c|c|c|c|c|c|}
\hline & Edible fruits & Timber & Fuelwood & Living tree & Seedlings & Charcoal & Seeds & Poles & Round wood \\
\hline Coffea canephora Froehner & 27 & & 1 & & 1 & & & & \\
\hline Persea americana Mill. & 18 & & 1 & & 1 & & & & \\
\hline Artocarpus heterophyllus Lam. & 17 & 1 & & & & & & & \\
\hline Maesopsis eminii Engl. & & 10 & 1 & 3 & 1 & & & 1 & 1 \\
\hline Mangifera indica L. & 12 & & 2 & & 1 & 1 & & & \\
\hline Milicia excelsa (Welw.) C. Berg & & 9 & & 1 & & & & 1 & \\
\hline Carica papaya $\mathrm{L}$. & 5 & & 1 & & & & 1 & & \\
\hline
\end{tabular}

TABLE 4: Conservation status of tree species.

\begin{tabular}{lccr}
\hline Species & Scarce & Abundant & Status \\
\hline Markhamia lutea (Benth.) K. Schum. & 14 & 19 & Abundant \\
Mangifera indica L. & 12 & 55 & Abundant \\
Artocarpus heterophyllus Lam. & 10 & 51 & Abundant \\
Pinus spp. & 10 & 30 & Abundant \\
Maesopsis eminii Engl. & 8 & 52 & Abundant \\
Persea americana Mill. & 2 & 26 & Abundant \\
Coffea canephora Froehner & 4 & 19 & Abundant \\
Ficus natalensis Hochst. & 9 & 18 & Abundant \\
Senna spp. & 1 & 9 & Abundant \\
Acacia spp. & 1 & 9 & Abundant \\
Carica papaya L. & 1 & 3 & Abundant \\
Milicia excelsa (Welw.) C. Berg & 67 & 1 & Scarce \\
Albizia coriaria Oliv. & 34 & 4 & Scarce \\
Citrus sinensis (L.) Osb. & 10 & 2 & Scarce \\
Eucalyptus spp. & 9 & & Scarce \\
Canarium schweinfurthii Engl. & 5 & Scarce \\
\hline
\end{tabular}

some like timber are sold in designated markets (12\%). It was not easy to determine the frequency for selling of products, apart from edible fruits that are sold twice a year on average. Everybody including children can sell tree products, although adults in the home are more involved.

Females mentioned slightly more species than males; however, there was no statistical association between species and gender $\left(\chi^{2}, P>0.05\right)$. Additionally, women tend to preferentially mention species that are used for firewood, medicine, and food compared to males who mentioned mostly species used for timber, charcoal, and those used in construction.

3.3. Farmer Perceptions on Conservation Status of Tree Species. Overall, woody species according to respondents are declining in abundance mostly because of destructive exploitation to get products like timber or charcoal $(80 \%)$, from clearing land for agriculture (9\%) or pests (9\%). The conservation status, specific to prioritised woody species, was determined in Bunya County by asking respondents to list species that are becoming scarce (hard to find) and those that are increasing or becoming abundant. A comparison was made on the perception of whether a species was increasing or declining based on a comparison of the numbers of respondents stating that a species was declining or increasing. And from this the greater of the two frequencies was taken to be the conservation status of the species (Table 4). For this reason the species Markhamia lutea (Benth.) K. Schum., M. indica, and $A$. heterophyllus are considered to be abundant, while M. excelsa and Albizia coriaria are considered to be scarce (Table 4).

Mayuge in the recent past has experienced increased sugar cane growing and this has forced people to convert large tracts of land to this crop. Other factors were pests and diseases, lack of knowledge on how to propagate woody species, and lack of planting materials or the fact that they are not planted or protected by farmers in the area. Abundant species are on the other hand increasing because they are planted or are protected by farmers when found growing naturally. The abundance of woody species was attributed to active husbandry by planting and protection as well on the intrinsic nature of the species in that they propagate easily. This is shown in Table 5 for the most popular species that include M. indica, M. eminii, A. heterophyllus, Pinus spp., and C. canephora.

3.4. Local Tree Husbandry Practices. Farmers in Bunya County are interested in tree planting and are actively 


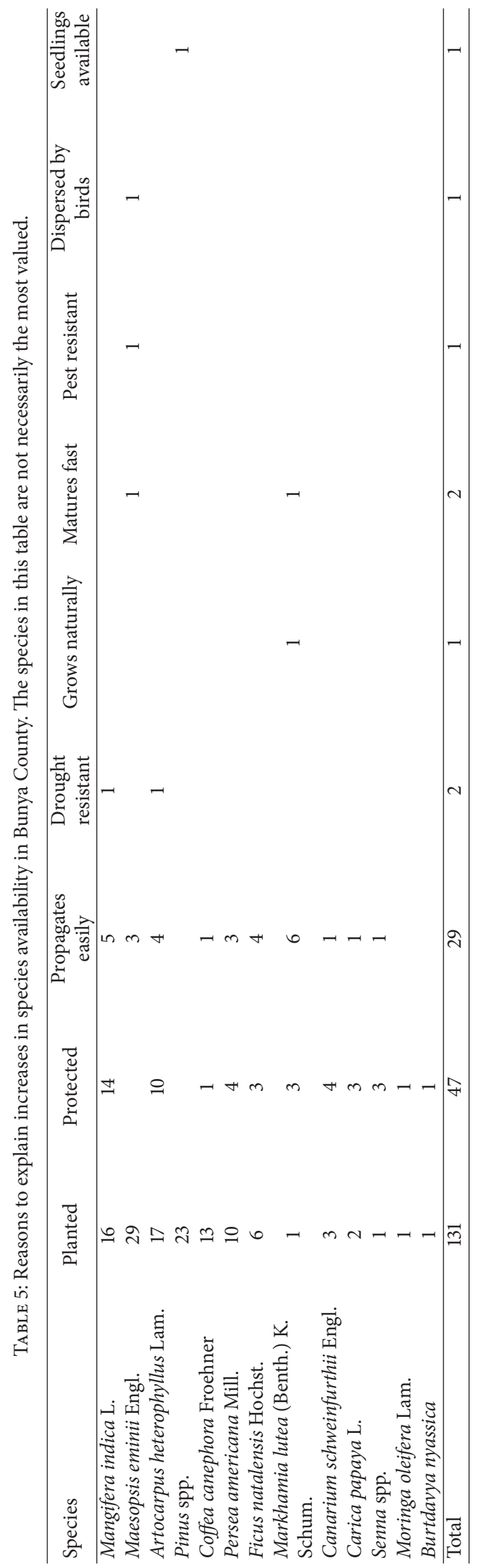


TABLE 6: Common tree management practices, planting materials, where trees are maintained, and source of planting materials as reported by respondents.

\begin{tabular}{|c|c|c|c|}
\hline Tree husbandry practices & Number & Planting materials & Number \\
\hline Planting & 28 & Seeds & 38 \\
\hline Protection against damage & 26 & Seedlings & 31 \\
\hline Pruning & 18 & Wildings & 27 \\
\hline Root suckering & 3 & Cuttings & 4 \\
\hline Location where trees are grown & & Source of planting material & \\
\hline Crop field & 42 & My land & 97 \\
\hline Backyard & 29 & Others (local administration $=2$; bought, neighbour) & 4 \\
\hline Compound or courtyard & 27 & & \\
\hline Hedge & 2 & & \\
\hline Along the road & 1 & & \\
\hline
\end{tabular}

TABLE 7: Sources of information for tree planting.

\begin{tabular}{lc}
\hline Sources of information & Frequency \\
\hline Radio & 37 \\
Seminars $^{1}$ & 16 \\
Other farmers & 16 \\
Relatives & 5 \\
School & 3 \\
Church and mosque & 3 \\
Others $^{2}$ & 4 \\
Environmental officers/representatives & 1 \\
Busoga Forest Company & 1 \\
Television & 1 \\
\hline
\end{tabular}

${ }^{1}$ Seminars include community meetings at subcounty (10 respondents), village (3), and others (3).

${ }^{2}$ Others include books, environmental officers/representatives, Busoga Forest Company, and television.

involved. All respondents who participated in this study had planted a tree in the last 5 years and were willing to plant more in future. Trees are propagated from seed, seedlings, wildings, and cuttings. Seedlings are prepared by farmers or purchased from nursery gardens managed by farmers (Table 6). All family members, including children, are involved in tree planting. Trees are maintained in crop fields, as well as around the home, in the home-garden (or backyard) or the compound/courtyard (Table 6). Planting as live fence in farm boundaries was not observed.

The people besides having an intrinsic interest in tree planting also receive encouragement from many different sources, chief among which is the radio, and from other farmers and village or other subnational meetings (Table 7).

3.5. Challenges That Affect Tree Planting. Farmers in Bunya County who did not plant trees were asked to give reasons that hinder them from planting trees and, according to them, the major reasons were pests (termites), drought, lack of land, diseases (that attack mostly coffee and oranges), and lack of seeds and seedlings (Table 8). Other factors that hinder tree planting mentioned by respondents were limited capital to buy planting materials, garden tools and chemicals for
TABLE 8: Constraints to tree growing.

\begin{tabular}{lc}
\hline Constraints & Frequency \\
\hline Pests, mostly termites and rarely moles (Nfuko) & 45 \\
Drought & 42 \\
Lack of land & 19 \\
$\begin{array}{l}\text { Tree diseases (coffee, oranges, and avocado are } \\
\text { mostly affected) }\end{array}$ & 9 \\
$\begin{array}{l}\text { Lack of seeds and seedlings } \\
\text { Lack of funds to purchase inputs, for example, }\end{array}$ & 9 \\
$\begin{array}{l}\text { fertilizers } \\
\text { Limited labour }\end{array}$ & 8 \\
$\begin{array}{l}\text { Domestic animals } \\
\begin{array}{l}\text { Lestruction or theft of seedlings } \\
\text { Lack of market for tree products }\end{array}\end{array}$ \\
$\begin{array}{l}\text { Government ban to stop people from cutting their } \\
\text { Some trees, for example, Mvule, cannot be }\end{array}$ \\
\begin{tabular}{l} 
intercropped with other crops \\
\hline
\end{tabular}
\end{tabular}

spraying, human and animal damage, limited labour, and poor propagation methods as well as government policies on tree harvesting.

\section{Discussion}

4.1. Priority Woody Species and Their Conservation Statuses. The 14 species prioritised in this study are valued mostly for their edible fruits, firewood, timber, and construction wood/poles. These benefits justify increased investment in the development of agroforestry systems that will contribute to food security [17]. Their role in income generation is low however; the computed use values were low for income generation and few people were involved in marketing of tree products. This seems to support the welfare maximisation theory described by Scherr [7]. According to this theory, rural people manage trees with the aim of having regular access to products that satisfy their household needs and not for income generation. Delayed return on investment and underdeveloped markets are cited as major barriers to 
agroforestry development [17]. The abundant tree species such as Artocarpus heterophyllus, Mangifera indica, and Pinus spp. have edible products and high quality timber and are sometimes sold to generate income for communities. They thus play an important role in household economies [17]. Over and above this, useful species are likely to create favourable attitudes that contribute to their active management for their conservation among farmers within agroforestry systems. Outside of agroforestry systems, the attribute of being useful may instead lead to overexploitation and sometimes destructive harvesting.

Different attributes have made many species easy to maintain in the community. The species that are perceived to be abundant all have fast rates of growth, are easy to propagate, and have high survival rates [18], and their planting materials are readily available. The other factor is that the species are actually grown or spared when found growing in the area. Similar factors for tree availability were reported in Balawoli County [19]. Furthermore, these species are mostly crop trees for which the technology to propagate, grow, and manage them is well developed. Indeed, the prioritised species are valued in many other areas in Uganda and outside Uganda. For instance, $M$. indica is highly valued all over Africa. It is highly likely that exchange and transfer of technologies between sites will be easy when the species are valued in many different locations compared to if the species were valued in only a small area like Bunya County and when the technology to grow them is not developed. This is good and increases the potential to manage them in agroforestry systems.

Some tree species are perceived to be declining in abundance: those that are slow growing species and those that are lowly valued by farmers. They are not actively managed by planting. The exceptions are Citrus sinensis and Eucalyptus spp. which, though fast growing, are declining in extent and numbers. Features contrary to those mentioned for abundant species, such as slow growth, are some of the reasons that dissuade farmers from growing tree species. Another factor for the decline is that the species are harvested destructively to get firewood, charcoal, or poles for building.

\section{Tree Management Challenges}

Two of the key reasons for not planting trees are linked to lack of knowledge on pest and disease management and can be addressed through training on pest and disease management. Other challenges such as lack of funds to purchase inputs, for example, fertilizers, have been recognized by the Ugandan government as a key bottleneck to tree planting and maintenance (NPA, 2010). More to that, sugar cane growing in Mayuge has taken most of the land that would be available for tree growing. These factors reduce the appeal for farmers to maintain tree species in agroforestry systems and will need addressing by the responsible institutions such as NAADS (National Agricultural Advisory Services) or NFA (National Forestry Authority) and others.

The challenge of land scarcity can be addressed by encouraging and incentivising farmers with large pieces of land to plant more trees on their farms. Elsewhere, in Kenya, farmers faced with land scarcity decided to use land borders or hedgerows, where trees least interfere with food crop growing [20]. This is an option worth investigating in Bunya County, where, presently, hedgerow is the least used land unit for tree growing.

Concerning seedlings, community level tree nurseries need to be established for easing access to seedlings of priority tree species. Care must be taken not to give farmers free seedlings as it has been observed that some farmers who receive free seedlings abandon them [21]. The government of Uganda should operationalise the National Tree Planting Act and relevant policies to provide finances to farmers to acquire capital for inputs. This will address the challenge of lack of capital and finances to purchase farm inputs and implements.

Over and above these factors, and notwithstanding the fact that the trees are presently valued for their subsistence value, increases in tree planting will not happen unless decent markets for tree products are created. The most important stimulus for active tree growing is presence of markets for tree products (ICRAF website). Residents of Bunya County are willing to collaborate with the government and other relevant stakeholders in maintaining priority woody species. This can be possible by providing them with inputs including seeds and seedlings for planting and chemicals for spraying, conservation education, and capital to buy equipment and land. Lack of land was a major hindrance to tree planting and conservation in the areas visited.

\section{Conclusions and Recommendations}

Opportunities for cultivating trees within Bunya exist because tree species are valued for their products. In this study we have generated a short list of 14 priority species that implementers can choose from when promoting tree planting. The priority species are valued mostly for their edible fruits, timber, firewood, and poles especially for construction purposes. Interventions to plant trees should focus on the priority species identified here, because these are the ones that farmers are interested in managing. According to Franzel et al. [22], tree planting interventions with farmers are likely to succeed when farmers' needs and preferences are properly assessed and respected by project implementers.

Trees are maintained in crop fields and home-gardens as well as in the compound and are propagated from seedlings, wildings, and cuttings. There is little evidence of commercial nursery tree operators. This shows that farmers cannot afford the cost of seedlings.

Many challenges that impact on tree growing have been identified in this study. The most significant in this study is that the market for nonwood tree products is very weak. If markets for tree products remain poor, farmers will not dedicate their best effort to tree planting and maintenance.

Farmers need training and sensitization on better methods of tree planting and management and the role of trees in climate change abatement. There is need to study markets of tree products in this area and other parts of Uganda to understand this value chain with a view to strengthening tree products markets and to provide a decent return on tree 
investment. There is also need to conduct an ecological study to determine the floristic composition and stocking rate of woody species in Bunya County. This will inform the need to plant trees and also the land use units on the farm where trees can be planted.

\section{Conflicts of Interest}

The authors declare that there are no conflicts of interest regarding the publication of this paper.

\section{Acknowledgments}

This study was supported by a Rockefeller Foundation funded project (no. 2009CL1323). In a special way, the authors would like to extend their sincere thanks to all the respondents for providing this information and to the local district administration for all the help they provided to the authors. Mr. Samuel Kakungu, the Local Council Chairperson of Buwaaya village, moved with the authors from home to home showing them households they needed to interview.

\section{References}

[1] FAO, State of the Worlds Forests, Food and Agriculture Organization of the United Nations, Rome, Italy, 2009.

[2] M. C. Hansen, P. V. Potapov, R. Moore et al., "High-resolution global maps of 21st-century forest cover change," Science, vol. 342, no. 6160, pp. 850-853, 2013.

[3] NFA, National Biomass Study: Technical Report 2005, National Forestry Authority, 2009.

[4] NEMA (National Environment Management Authority), State of The Environment Report for Uganda 2010, NEMA, 2010.

[5] R. Drigo, WISDOM (Woodfuel Integrated Supply/Demand Overview Mapping) - East Africa, FAO, Rome, Italy, 2006.

[6] J. Obua, J. G. Agea, and J. J. Ogwal, "Status of forests in Uganda," African Journal of Ecology, vol. 48, no. 4, pp. 853-859, 2010.

[7] S. J. Scherr, "Meeting household needs: farmer tree-growing strategies in western Kenya," in Tree Management in Farmers Strategies: Responses to Agricultural Intensification, J. E. M. Arnold and A. P. Dewees, Eds., pp. 141-173, Oxford University Press, Oxford, UK, 1995.

[8] B. W. Miller, P. W. Leslie, and J. T. McCabe, "Coping with natural hazards in a conservation context: resource-use decisions of Maasai households during recent and historical droughts," Human Ecology, vol. 42, no. 5, pp. 753-768, 2014.

[9] S. S. Meijer, D. Catacutan, O. C. Ajayi, G. W. Sileshi, and M. Nieuwenhuis, "The role of knowledge, attitudes and perceptions in the uptake of agricultural and agroforestry innovations among smallholder farmers in sub-Saharan Africa," International Journal of Agricultural Sustainability, vol. 13, no. 1, pp. 4054, 2015.

[10] S. J. Scherr, "The role of extension in agroforestry development: evidence from western Kenya," Agroforestry Systems, vol. 18, no. 1, pp. 47-68, 1992.

[11] N. T. Hansen, A. Raebild, and H. H. Hansen, "Management of trees in northern Ghana - when the approach of development organizations contradicts local practices," Forests Trees and Livelihoods, vol. 21, no. 3-4, pp. 241-252, 2012.
[12] Mayuge District, Mayuge District Local Government Five Year Development Plan (2010/2011-2014/2015), Mayuge District, 2011.

[13] UBOS, National Population and Housing Census 2014: Subcounty Report-Eastern Region, Uganda Bureau of Statistics, Kampala, Uganda, 2016.

[14] A. M. Lykke, "Local perceptions of vegetation change and priorities for conservation of woody-savanna vegetation in Senegal," Journal of Environmental Management, vol. 59, no. 2, pp. 107-120, 2000.

[15] J. A. Van Den Brakel, R. Vis-Visschers, and J. J. G. Schmeets, "An experiment with data collection modes and incentives in the dutch family and fertility survey for young moroccans and turks," Field Methods, vol. 18, no. 3, pp. 321-334, 2006.

[16] A. Nyamukuru, A. Nabatanzi, S. Mpiira, and J. R. S. Tabuti, "Locally preferred woody species and their management in Kiruhura and Arua districts, Uganda," Ethnobotany Research and Applications, vol. 14, pp. 49-61, 2015.

[17] FAO, "Advancing agro forestry on the policy agenda: a guide for decision makers," in Agro Forestry Working Paper No. 1, G. Buttoud, O. Ajayi, G. Detlefsen, F. Place, and E. Torquebiau, Eds., p. 37pp, Food and Agriculture Organization of the United Nations, Rome, Italy, 2013.

[18] A. B. Katende, A. Birnie, and B. Tengnäs, Useful Trees and Shrubs for Uganda, Identification: Propagation and Management for Agricultural and Pastoral Communities, 2010. National Development Plan (2010/11-2014/15), Regional Soil Conservation Unit. National Planning Authority, Kampala, The Republic of Uganda, 1995.

[19] J. R. S. Tabuti, "Important woody plant species, their management and conservation status in Balawoli sub-county, Uganda," Ethnobotany Research \& Applications, vol. 10, pp. 269-286, 2012.

[20] M. M. Backes, "The role of indigenous trees for the conservation of biocultural diversity in traditional agroforestry land use systems: The Bungoma case study: In-situ conservation of indigenous tree species," Agroforestry Systems, vol. 52, no. 2, pp. 119-132, 2001.

[21] M. Nieuwenhuis and N. O'Connor, "Challenges and opportunities for small-scale tree nurseries in the East African highlands," Unasylva, vol. 51, no. 203, pp. 56-60, 2000.

[22] S. Franzel, H. Jaenicke, and W. Janssen, "Choosing the right trees: setting priorities for multipurpose tree improvement," ISNAR Research Report 8, International Service for National Agricultural Research, The Hague, The Netherlands, 1996. 

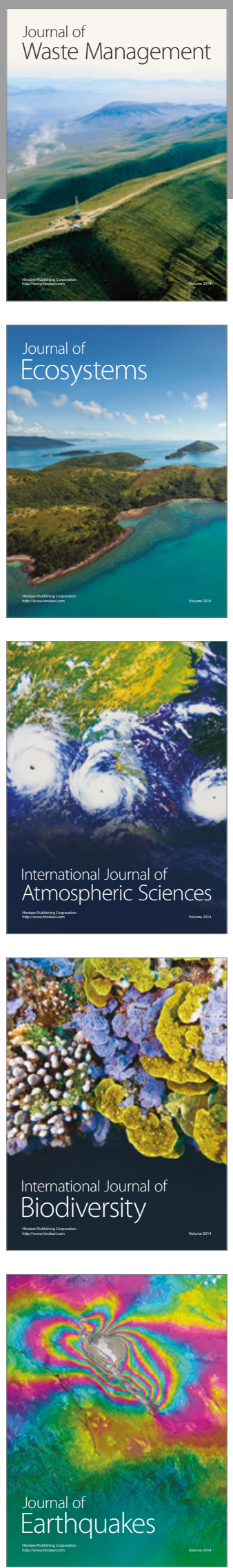
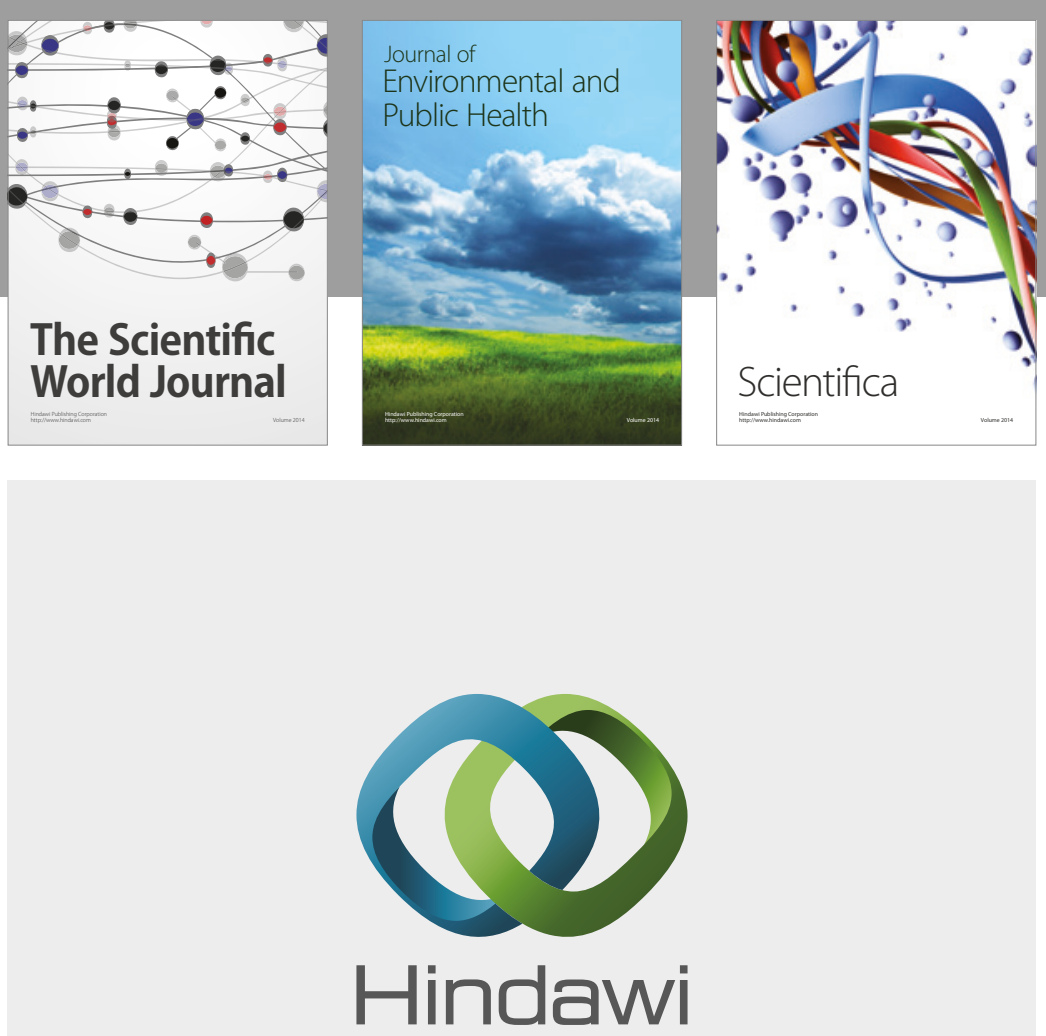

Submit your manuscripts at

https://www.hindawi.com
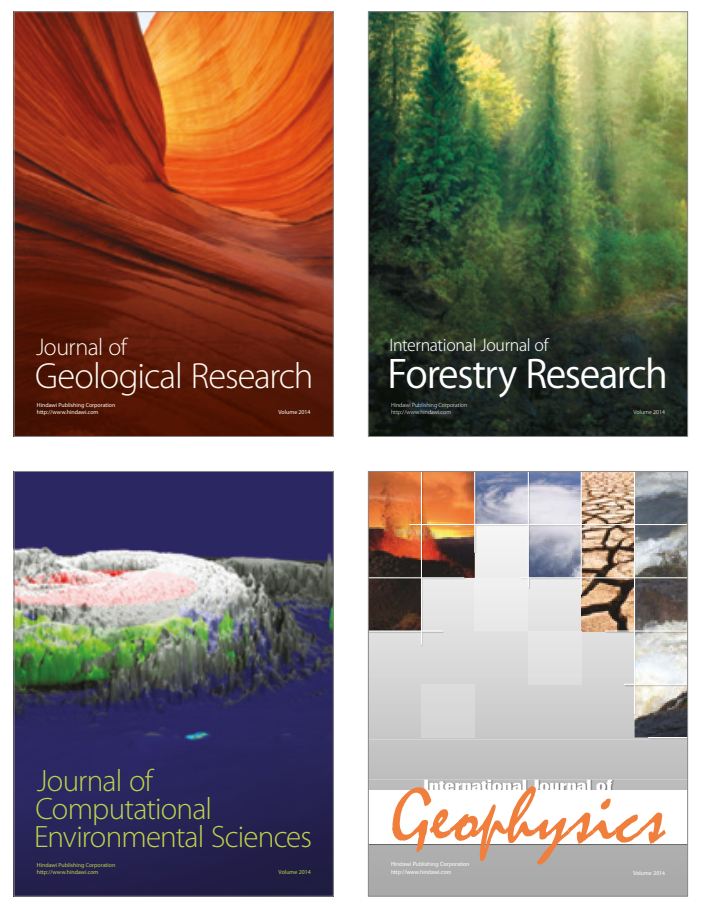
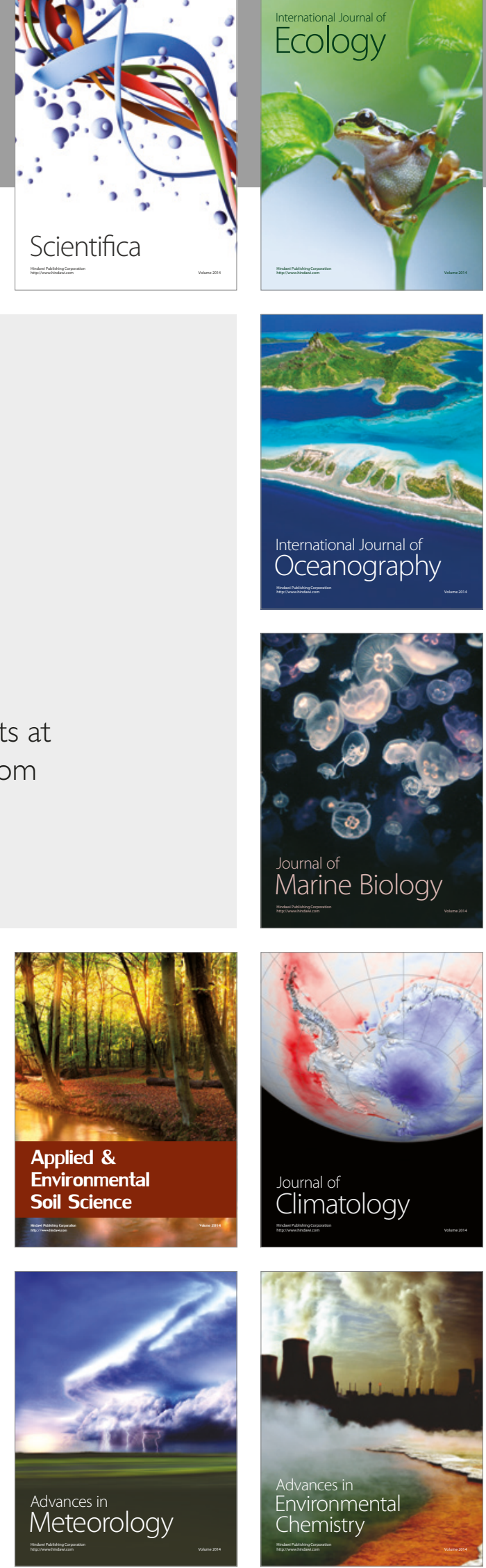